\title{
UNA POSIBLE OBRA DESCONOCIDA DE EL GRECO
}

Entre el riquísimo patrimonio artístico que albergó el tristemente desaparecido convento de Madres Capuchinas de Toledo, abundaban en las celdas de las madres cruces de madera con la figura de Cristo pintada sobre ellas. Desde hace tiempo venía llamando la atención una de estas figuras por su estilo que apunta "a la manera" de El Greco y que una cuidadosa restauración reciente, llevada a cabo por el restaurador Rafael Alonso, ha dejado en magnífico estado.

La cruz mide $0.44 \mathrm{~ms}$. y la figura en ella pintada $0,22 \mathrm{~ms}$. El Cristo muestra esa tensión espiritual típica de la pintura de época madura del Cretense y representa a un Salvador ya muerto con la herida del costado sangrante. El cuerpo tiene una distorsión de las formas corporales que en parte se desvanecen o diluyen en el fondo oscuro en el que la imagen se destaca. Los brazos, muy largos, resultan casi horizontales a la cruz. El paño de pureza, muy sumario, cruza las caderas de la figura, desde la derecha y cae por el lado izquierdo hasta la zona del muslo. Se distingue este Cristo de todas las versiones conocidas de $\mathrm{El} \mathrm{Greco}^{1}$ en que aparece con la cabeza inclinada y caída sobre un hombro, dejando así constancia de estar pintado en momento posterior a la muerte, mostrando una contención o laxitud de la que carecen todos sus otros Crucifijos conocidos. En las

1 Wethey, Harold E., El Greco y su Escuela, T. I, láms. 66 y 162 a 174, Ed. Guadarrama, S. A., Madrid, 1967. 


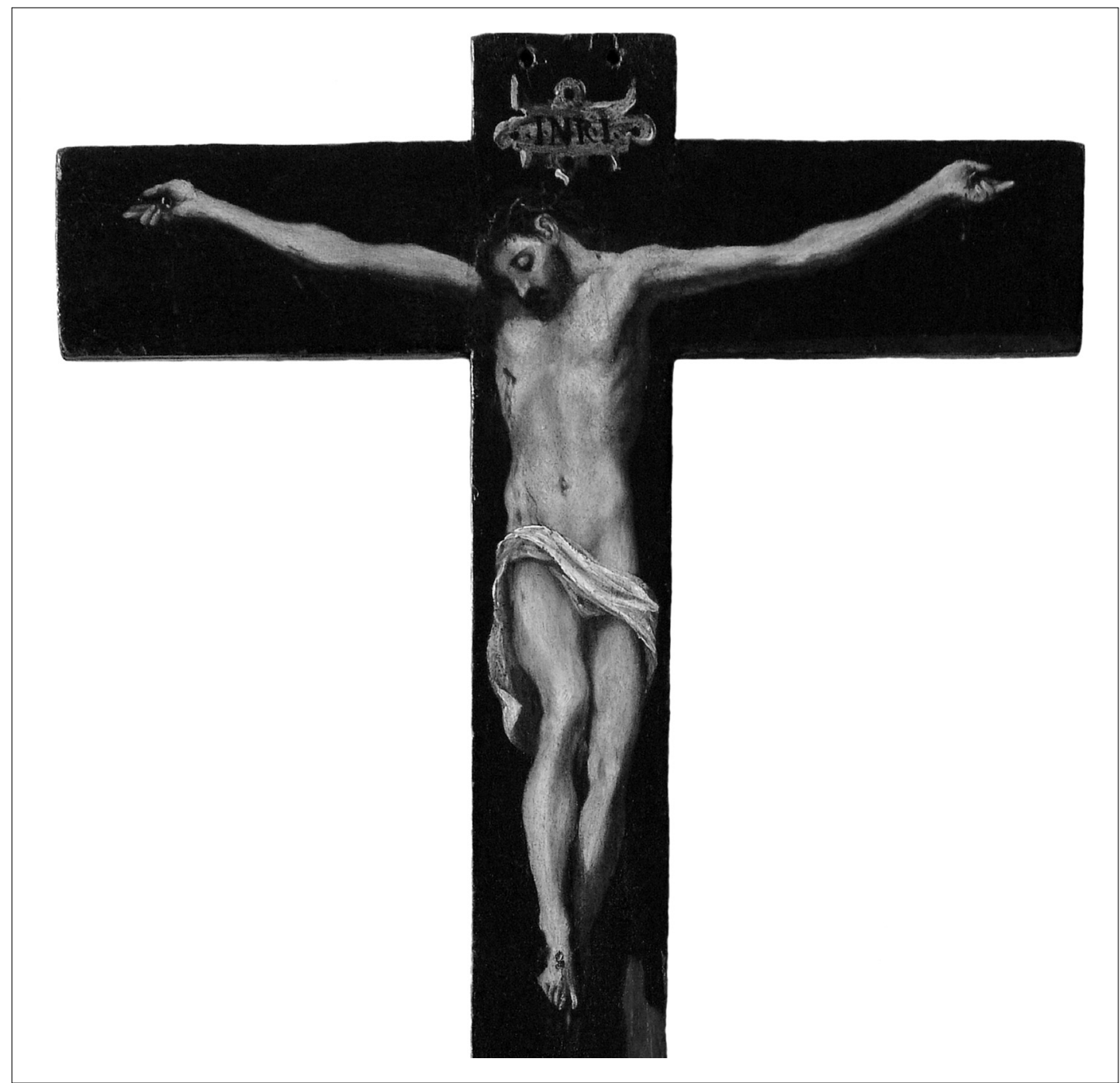

El Greco (?). Crucificado. Toledo. Madres Capuchinas.

otras versiones del pintor el Crucificado aparece vivo, sin la herida sangrante del costado, y mostrando la cabeza erguida dirigiendo la mirada hacia el cielo en un gesto de súplica. También tenemos en esta pequeña versión un letrero con el INRI en todo distinto a lo hasta ahora conocido, no aparece escrito en varios caracteres y de tamaño considerable sino solamente las cuatro letras latinas en una pequeña cartela, que en parte viene dado por el tamaño y forma de la cruz. A los pies del madero, en una gran penumbra, aparece una calavera con las tibias cruzadas que solo vemos en algunas de las otras versiones conocidas, aunque vistas con un planteamiento más informal o distinto.

De todas las versiones conocidas, salvando la distancia del tamaño, la que parece más cercana a esta pequeña pintura es la gran Crucifixión que guarda el Museo del Prado, muy probablemente 
procedente del retablo del Colegio de Doña María de Aragón ${ }^{2}$. En estas dos versiones vemos a Cristo con la llaga en el costado de la que brota la sangre. Son también las dos únicas versiones que conocemos en el que sea la pierna derecha la que monta sobre la izquierda y no al revés como ocurre en todas las otras Crucifixiones conocidas. El dibujo del paño de pureza sigue líneas semejantes aunque mucho mas simplificado en este ejemplar que presentamos, que guarda una cierta relación también con el dibujo del paño de pureza de "la Crucifixión con donantes" del Museo del Louvre. Es en todo semejante a las pinturas seguras de el Cretense el modo en que están tratados los dedos de las manos clavadas al madero, la manera en que están dadas las breves pinceladas de sangre y de modo especial la característica manera de dibujar con breve trazo el clavo de los pies. Es, sin embargo, desconcertante el rostro de la pequeña figura en parte cubierto con una tupida barba oscura que resulta lo más problemático de la imagen. Por otra parte la corona de espinas, muy marcada en los Cristos crucificados del pintor, aquí solamente se insinúa. Como afirma la Dra. Palma Martínez - Burgos refiriéndose al Crucifijo del Museo del Louvre, el pintor "presenta una imagen cuya sobriedad realza la fuerza espiritual que contiene"3.

No sería la primera obra de El Greco que se conservaría en este convento, ya es generalmente conocido "el Velo de la Verónica" que aquí se guarda y que dio a conocer el profesor Pérez Sánchez ${ }^{4}$. No debemos olvidar que el Cardenal fundador del monasterio, don Pascual de Aragón, fue un auténtico gustador de obras de arte y gran mecenas en la España del siglo XVII, durante los reinados de Felipe IV y Carlos II, y no ahorró esfuerzos para que su comunidad capuchina albergase las más hermosas piezas artísticas del momento.

También queremos finalmente resaltar como en los inventarios de El Greco y de su hijo Jorge Manuel aparecen reseñadas varias Crucifixiones de distintos tamaños ${ }^{5}$.

JuAn Nicolau CASTRO Doctor por la U.A.M.

\footnotetext{
2 PÉrez SÁnchez, Alfonso E., "Las series dispersas del Greco" en el Catálogo de la Exposición El Greco de Toledo, Museo del Prado, Madrid, 1982, pág. 161.

3 MartíneZ -Burgos García, Palma, El Greco. El pintor humanista, obra completa, Ed. LIBSA, Madrid, 2005, pág. 290.

4 Pérez Sánchez, Alfonso E., Catálogo de la Exposición El Toledo de El Greco, Toledo, 1982, pág. 139.

5 Marías, Fernando, El Greco. Biografía de un pintor extravagante, Ed. Nerea, S. A., 1997, págs. 312 a 315.
} 